Zacharias, J., Han, X., \& Chen, Y. (2020). Afterschool Activity of Children Living in Urban Villages and Planned Communities in Shenzhen. Landscape Architecture Frontiers, 8(2), 26-35. https://doi.org/10.15302/J-LAF-1-020022

\section{深圳城中村及正规居住区内儿童离校后 活动情况调亘研究 \\ AFTERSCHOOL ACTIVITY OF CHILDREN LIVING IN URBAN VILLAGES AND PLANNED COMMUNITIES IN SHENZHEN}

\section{约翰 · 扎卡赖亚斯}

北京大学建筑与景观设计学院讲席教授, 北京大学城市过程模拟与应用实验室主任

\section{韩西丽*}

北京大学深圳研究生院城市规划与设计学院副教授

陈义勇

深圳大学建筑与城市规划学院副教授

\section{John ZACHARIAS}

Professor of College of Architecture and Landscape of Peking University; Director of Laboratory for Urban Process Modelling and Applications in Peking University

\section{HAN Xili}

Associate Professor of School of Urban Planning and Design, Peking University Shenzhen Graduate School

\section{CHEN Yiyong}

of School of Architecture and Urban Planning Shenzhen University

\section{*通讯作者}

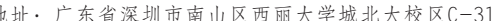

邮编: 518055

管: hanx1@pkusz.edu.ch
摘要

放学离校后是儿童日常体力活动的主要时 段。本次研究旨在填补人们对于中国初中生离校 后活动的认知空白。为了了解深圳城中村儿童及 正规居住区儿童的离校后活动情况, 本研究选取 了深圳三所位于典型学区内的中学, 并随机抽取 班级进行问卷调查, 最终收回366份完整问卷, 并获取了一周5个工作日内学生进行中高强度体力 活动（MVPA）、参加课外班、久坐情况, 以及 上下学出行路线的完整数据。研究发现, 积极出 行距离越远, 产生的MVPA越多, 且积极出行存 在距离阈值。与家住正规居住区的儿童相比, 居 住在城中村的儿童出行距离更远, 进行的MVPA 更多。不同儿童的MVPA水平差异显著, 但 MVPA与课外班的数量以及上下学的交通方式无 关。尽管研究结果表明, 中国初中生的离校后活 动水平高于西方国家, 但相关积极活动在初三一 年被迫终止, 原因是初三学生需要将几乎所有时 间都投入到准备高中入学考试之中。本次研究揭 示了社会背景以及住所 - 学校距离远近对于中国 儿童进行MVPA的重要性, 并指出虽然当前的城 市规划有助于儿童实现积极出行, 但仍需进一步 削减日益增加的机动车辆、宽马路、障碍物等因 素对儿童出行造成的不利影响。

\section{关键词}

儿童; 体力活动; 中高强度体力活动; 积极出行; 城中村; 中学; 课外班

\section{ABSTRACT}

Afterschool is an important time period for children to improve their weekday physical activity. This study aimed at filling a gap in people's knowledge of middle school children's afterschool activity in China. In order to study afterschool activity of children living in urban villages and planned communities in Shenzhen, a questionnaire was applied in three schools located in the typical school districts in Shenzhen, aimed at a 100\% sample of randomly selected classrooms. Complete data for moderate-to-vigorous physical activities (MVPA), cram schools, sedentary activities, and the itineraries of their school-to-home commutes were obtained for 5 weekdays in one week in an in-class survey, for a total of 366 complete surveys. It was found that a greater active commuting distance from school generated more MVPA, and there was a distance threshold for active commutes. Children residing in urban villages travelled farther and engaged in more MVPA than did children in planned residential areas. MVPA varied greatly among children but was unrelated to the number of cram schools or transport mode to school. Although these results showed greater levels of afterschool activity than that have been found generally in surveys in Western contexts, such active activity terminates in the final year of middle school when students devote nearly all available time to study for high school entrance exams. This study revealed the importance of social context and distance to school for children's MVPA in China, and pointed out that the current urban planning contributes to active travel of children but needs further adjustment to mitigate the effects of increasing motorization, bigger roads, and physical barriers to movement.

\section{KEYWORDS}

Children; Physical Activity; Moderate-to-Vigorous Physical Activity (MVPA); Active Commuting; Urban Village; Middle School; Cram School

基金项目

中国国家自然科学基金项目“城市空间过滤渗透性对儿童非机动通勤的影响强度与机制研究”（编号：41471119）

\title{
RESEARCH FUND
}

Research on the Effect of Filtrated Permeability of Urban Spaces on Children's Active School Commuting, National Natural Sciences Foundation of China (No. 41471119)

编辑 田晓劼 翻译 田晓劼 田乐

EDITED BY TIAN Xiaojie TRANSLATEd BY TIAN Xiaojie Tina TIAN 


\section{1 引言}

由于中国城市在地域环境、学区政策、儿童教育水平上存在显著 差异, 且收人差距不断扩大, 中国城市儿童问题尤为引人关注, 但据 作者所知, 鲜有研究从上述方面对儿童健康议题进行深人探讨。在美 国, 通常低收人人群和少数族裔更容易患有肥胖症和久坐引发的非传 染性疾病, 对于生活在贫困地区的学童来说尤其如此 ${ }^{[1]}$ 。北美和欧洲 多地已从社会一人口结构视角探索了导致这一健康水平差异的原因。 在中国, 人们的健康水平也存在巨大差异, 但情形截然不同。近年来 中国经济地位不断提高、城镇化持续推进，公众健康水平却越发令人 担忧 ${ }^{[2]}$ 。城乡人口收人差异亦十分显著, 尽管农民可以进城务工, 但 他们通常无法享受到和城市居民一样的全部城市服务, 因此城乡差距 也出现在城市内部。目前, 中国患有肥胖症的人数已超过美国 ${ }^{[3]}$, 但 不同的是, 中国的肥胖症和非传染性疾病与城市环境密切相关, 且患 者多为社会经济地位较高人群 ${ }^{[4]}$ 。2006年, 在业余时间进行运动锻炼 的中国男性和女性比例仅为 $13.2 \%$ 和 $8.4 \%$ \% ${ }^{[5]}$ 。 中国健康与营养调查》 首次指出, 自1997年起中国的积极出行比例不断下降一从1997年的 46\%（步行）及51\%（骑行）下降至2006年的28\%（步行）及33\%（骑 行) 。此后, 这一比例呈逐年下降的态势 ${ }^{[5][6]}$ 。例如, 北京的自行车通 勤率从1986年的 $62.7 \%$ 下降到2014年的 $11.5 \%$ 。

其中, 儿童上学途中的积极出行骤减令人尤为担忧 ${ }^{[8]}$, 而童年时期 形成的日常行为习惯将长期影响其日后的行为模式和健康状况 ${ }^{[9[110]}$ 。本 文重点研究影响学童离校后活动的社会一人口结构和地理因素, 特别 是那些会影响中高强度体力活动 (MVPA) 的课外教育, 以及与地理位 置和MVPA相关的出行方式选择。MVPA通常是指可导致心率达到最大 值 $64 \%$ 的活动 ${ }^{[11]}$, 如步行、骑行、踢建子、器械锻炼等。本研究选取中 国城镇化程度较高的重要城市之一深圳进行调查研究, 以探究离校后 活动是否会影响儿童回家 (或去往其他目的地) 途中的积极出行以及 相关的MVPA情况。

\section{Introduction}

The Chinese case is of particular interest because of differences in urban geography, school districting policy, child education, and a widening income gap, none of which has been investigated in any depth with regard to children's health, to the knowledge of the authors. In the United States, it is often found that lowincome and minority individuals are more likely to suffer from obesity and non-communicable diseases associated with sedentariness. This is particularly the case for school children living in deprived localities ${ }^{[1]}$. The reasons for this disparity in health status along socio-demographic lines have been explored in a variety of contexts in North America and Europe. In China, there is also a strong health divide, but it is on quite different lines. Rising economic status and urbanization in China are strongly associated with a decline in public health ${ }^{[2]}$. Income disparities are most notable on the urban-rural divide, which extends into cities as rural migrants move to cities but generally do not have access to the full range of urban services available to urban citizens. China now has a larger population of obese individuals than the United States ${ }^{[3]}$. But in China, obesity and non-communicable diseases are strongly associated with the urban environment and with higher socio-economic status $^{[4]}$. Only $13.2 \%$ of Chinese men and $8.4 \%$ of women declared that they engaged in any leisure-time exercise in $2006^{[5]}$. Overall, active transport declined in China from 1997, which was first included in the China Health and Nutrition Survey. In that survey, active transport rate declined from $46 \%$ (walking) and 51\% (bicycling) in 1997 to 28\% (walking) and $33 \%$ (bicycling) in 2006. Then it further declines ever since ${ }^{[5][6]}$. For example, bicycle commutes in Beijing declined from $62.7 \%$ modal share in 1986 to $11.5 \%$ in $2014^{[7]}$.

A dramatic drop in active commuting by children from school is particularly worrisome ${ }^{[8]}$. Daily behavior habits acquired in childhood have long-term consequences in behavior and health outcomes ${ }^{[9][10]}$. This study focuses on sociodemographic and geographical factors in afterschool activity, in particular the related extra-curricular education to moderateto-vigorous physical activity (MVPA), and transport mode choice to geography and MVPA. MVPA is generally defined as the activity leading to heart rate at $64 \%$ of the maximum ${ }^{[11]}$, including walking, bicycle riding, shuttlecock, and fitness equipment training. The study is carried out in Shenzhen, a major urbanized city in China, to identify whether children's afterschool activity interferes with their active commuting and with associated MVPA as part of the commute home or at other times. 
鉴于学童的课外班多由父母安排, 本研究试图探究：是否如某些 文献所述，这样的课外班会侵占儿童课外时间，从而减少积极出行 ${ }^{[12]}$ ? 同西方国家一样, 中国的高收人家庭汽车保有率较高, 而私家车的普 及也与较低的儿童积极出行率紧密相关 ${ }^{[13]}$ 。中产阶级家庭的儿童有条件 进行课外班学习, 其中大多以提高学习成绩为目的, 而低收人家庭由 于无力支付高昂的费用, 通常不会将他们的孩子送人课外班。其中, 收人最低的家庭通常居住于城中村。城中村是指由于城市扩张而被吞 没的乡村社区，但仍由原住村民进行管理。原住村民通常只占城中村 居民的小部分，大多数居民是低收人且没有私家车的农村移民。深圳 的正规居住区内一般建有配套的绿地和游乐空间，相形之下，城中村 内可能只有小型的硬质开放空间或狭窄的人行道可供居民逗留玩要。 另一方面, 城中村底层商铺众多, 土地利用方式更为混合多样, 而大 多数正规居住区内则少有或没有商业用地。本研究认为, 了解由于收 人水平、交通方式、生存状况的不同而导致不同社区类型的儿童健康 状况存在差异十分重要。

中国的“学区” 概念大约自 20 世纪 80 年代提出, 在学区内的非机 动车环境中, 儿童可采用积极出行方式上下学 ${ }^{[14]}$ 。深圳作为一座目前拥 有超过 1400 万居民的城市，几乎完全是在1980年之后规划和建设起来 的。除极个别情况外, 居住在某一学区内的中学生必须在该学区内的 学校就读。本研究聚焦的问题包括: 学区内的儿童是否都可以通过非 机动交通方式上下学? 地理位置和距离是否是影响儿童出行方式选择 的因素? 一项研究表明, 学生住所和学校之间的距离越远, 其MVPA水 平越高 ${ }^{[15]}$; 然而, 当距离达到一定阈值时, 积极出行方式会转变为机动 车出行。与之相关的问题是：出行模式的不同是否会对MVPA的发生次 数和地点产生影响?

儿童在上下学途中进行的体力活动是其日常体力活动的重要组成 部分 ${ }^{[16[17]}$, 而放学后的课外时间和周末是小学生进行体力活动最为活跃 的时段 ${ }^{[18]}$ 。针对美国南卡罗来纳州的研究表明, 儿童放学路上的积极出
Since such supplemental education, or "cram school," is often organized by the parents, the question is whether such parental control in the afterschool period leads to lower active transport by children, as is suggested in the literature ${ }^{[12]}$. In China, as in the West, higher income households have more cars and the vehicle prevalence is strongly associated with lower rates of active transport among children ${ }^{[13]}$. Children from the middle classes in China have access to supplemental education after school hours, much of it related to performance in the regular curriculum. Lower income families living in urban villages generally do not enroll their children in cram schools because of the substantial cost. Lowest income households generally reside in the so-called urban villages (Chengzhongcun). Urban villages are the former rural communities, now engulfed by expanding urban environments but remaining under the management of the original villagers. While the villagers are often a small minority of those who inhabit these villages in the city, the great majority of inhabitants are rural migrants with low incomes and no cars. Planned residential communities constitute the remainder of the living habitat of Shenzhen and include green areas and playgrounds, whereas urban villages may only have small paved open spaces or narrow pedestrian streets for informal play. On the other hand, urban villages have mixed land use, with many small shops at the ground floor, while most planned residential communities in the city have little or no commercial land use. It is important to know the differences in the health status of children in each category of community within the city, because of these differences in income, transport choice, and living situation.

The school district in China since about 1980s is conceived as a non-motorized environment where children may commute actively to and from home ${ }^{[14]}$. Shenzhen, now a city with more than 14 million residents, was almost entirely planned and built up after 1980. Middle school children residing within an urban school district must attend the local school, with rare exceptions. There remains the question, then, whether all children within such districts can access the school by non-motorized transport or whether geography and distance play a role in the commuting mode choice. One study on the effect of distance to school suggested that higher levels of MVPA were associated with greater distance from school ${ }^{[15]}$; however, a switch from active to motorized transport may occur at a distance threshold. Related to this question is whether the commuting mode choice will have effects on the amounts and location of MVPA.

The contribution of the school journey to daily physical activity is substantial in young children ${ }^{[16][17]}$, with the afterschool period and weekends being the most active periods for primary 
行相当于进行了 24 分钟的 $\mathrm{MVPA}^{[19]}$ 。在中国香港，小学生每天 $56 \%$ 的步 行活动是在放学后进行的 ${ }^{[20]}$ 。中国父母通常会在天气和空气质量良好的 情况下, 在晚餐后将孩子带到户外活动——这通常也是城市居民区内 的开放空间和公园使用率最高的时段。

\section{2 研究方法}

在获得北京大学生物医学研究伦理委员会的审批 (第2015063号) 以及征得深圳市南山区教育局的许可之后, 本研究得以在深圳市内的 三所中学开展调研。这三所学校都位于典型的学区之中一一既包括 城中村学区, 也包括正规居住区学区。南山区教育局在其官方网站上 发布了本次调研活动的通知, 并面向所有教师定期更新相关内容。随 后, 研究人员与三所中学的校长取得联系, 并由校长推荐了各自中学 的体育老师来协助调查的推进工作, 并就问卷中某些具体活动向学生 释义。此外, 两名硕士生助理负责问卷的分发和收集。

初中共设三个年级, 但由于初三学生需要集中精力准备高中人学 考试, 老师们不希望他们因调研活动分散精力, 因此应校长要求, 本 次调研不包括初三学生, 仅针对初一和初二年级 (12 15岁) 的学生。 研究人员从每所学校的每个年级随机选取三个班级, 班级内的所有学 生均参与调查问卷的填写。调研分为 5 天进行, 学生们每天都需要回答 一系列针对特定课外活动 (既包含积极体力活动, 也包含久坐活动) 的问题 (含开放式问题 ), 并需要在附于问卷的地图上标记出他们住 所的位置、放学回家的路线, 以及途中玩要、停留或进行其他活动的 地点。

本次调查共分发了 587 份问卷, 收回543份。由于部分问卷未回答 全部问题或缺少详细的地图信息, 因此本次调查的最终样本为在一周 5 个工作日内完成的366份问卷。

本文的第二作者根据第一作者的意见准备了问卷内容, 联络了 与本次研究相关的组织机构和人员, 并对问卷的分发和收集进行了监 school children ${ }^{[18]}$. Active commutes were found to be equivalent to 24 minutes of MVPA in South Carolina, USA ${ }^{[19]}$. In Hong Kong, China, $56 \%$ of daily steps by primary school children took place after school ${ }^{[20]}$. It is also common practice throughout China for parents to take children outdoors after the evening meal, when weather and air quality allow it. These are generally the busiest times for open spaces and parks in urban residential areas.

\section{Study Methods}

Ethical approval was obtained from the Bio-medical Research Ethics Board of Peking University (No. 2015063), and the Education Bureau of Nanshan District of Shenzhen was approached for the permission, to conduct surveys in the classrooms of three middle schools in Shenzhen. These schools locate in the typical school districts which include urban villages and planned communities. The bureau issued a notice on their website that was accessed by all teachers on a regular basis. The principals of the three schools were then contacted, who also introduced the physical education teachers at those middle schools. These teachers assisted in the conduct of the survey, explaining to the students what was meant by certain activities in the survey. Two master student assistants physically distributed and collected the surveys from the students.

Middle schools are in three grades. The third grade was avoided at the request of the principals, since those students spend all free time studying for entrance exams to high school and the teachers did not want them disturbed from this activity. So the study concentrated on the first and second grades (between 12 to 15 years old). Three classes from each grade of each school were randomly selected for application of the survey. All students in the class participated. The survey was in five parts, each corresponding to one day. Each day survey had a series of questions on specific extra-curricular activities, both active physical activity and sedentary activity. Open questions were also included. For each day, students also traced their itinerary home from school on an attached map and marked home location, and places where they played, stopped, or engaged in activities.

In total, 587 questionnaires were distributed and 543 were returned. Some of the questionnaires were missing responses or lacked map details, such that the final sample reported here is 366 complete responses for 5 weekdays in one week of activity.

The second author prepared the questionnaire materials with input from the first author. The second author also made all the local contacts and supervised the distribution and collection 
表1：366名儿童在2016年5月一周5个工作日内的出行及活动数据汇总

Table 1: Summary of the commuting and activity data of 366 children in a 5-weekday period in May, 2016

\begin{tabular}{|c|c|c|c|c|c|c|c|}
\hline & $\begin{array}{c}\text { 平均出行距离 }(\mathrm{m}) \\
\text { ( 标准差 ) } \\
\text { Mean commute } \\
\text { distance (m) (SD) }\end{array}$ & $\begin{array}{c}\text { 积极出行学生百分比 } \\
\text { Active commuting } \\
\text { proportion }\end{array}$ & $\begin{array}{c}\text { 平均积极出行距离 ( } \mathrm{m} \text { ) } \\
\quad \text { 标准差 ) } \\
\text { Mean active commuting } \\
\text { distance (m) (SD) }\end{array}$ & $\begin{array}{c}\text { 课外班/周 (个) } \\
\text { Cram schools I } \\
\text { week (no.) }\end{array}$ & $\begin{array}{l}\text { MVPA/周 (次) } \\
\text { MVPA / week (no.) }\end{array}$ & $\begin{array}{c}\text { 最短出行距离 ( } \mathrm{m} \text { ) } \\
\text { (标准差) } \\
\text { Shortest commuting } \\
\text { distance (m) (SD) }\end{array}$ & $\begin{array}{l}\text { 积极出行距离与MVPA } \\
\text { 的相关系数 ( } r \text { 值 ) } \\
\text { Active commuting } \\
\text { distance / MVPA (r) }\end{array}$ \\
\hline $\begin{array}{l}\text { 正规居住区 } \\
\text { Planned residential } \\
\text { community }\end{array}$ & $1,110(654)$ & $70 \%$ & $834(477)$ & 1.61 & $8.0(7.4)$ & $96(163)$ & \multirow{12}{*}{$0.13(p=0.05)$} \\
\hline $\begin{array}{l}95 \% \text { 的置信度区间 } \\
95 \% \text { conf. int. }\end{array}$ & \pm 82 & & \pm 76 & & \pm 0.9 & & \\
\hline $\begin{array}{l}\text { 步行 } \\
\text { Walking }\end{array}$ & $753(452)$ & & & & & & \\
\hline $\begin{array}{l}\text { 骑行 } \\
\text { Bicycle }\end{array}$ & $1,128(455)$ & & & & & & \\
\hline $\begin{array}{l}\text { 私家车 } \\
\text { Private car }\end{array}$ & $1.840(460)$ & & & & & & \\
\hline $\begin{array}{l}\text { 公共交通 } \\
\text { Public transport }\end{array}$ & $1,737(572)$ & & & & & & \\
\hline $\begin{array}{l}\text { 城中村 } \\
\text { Urban village }\end{array}$ & $1,513(741)$ & $42 \%$ & $1,139(524)$ & 0.64 & $9.9(6.8)$ & $176(215)$ & \\
\hline $\begin{array}{l}95 \% \text { 的置信度区间 } \\
95 \% \text { onf. int. }\end{array}$ & \pm 119 & & \pm 125 & & \pm 1.19 & & \\
\hline $\begin{array}{l}\text { 步行 } \\
\text { Walking }\end{array}$ & $996(427)$ & & & & & & \\
\hline $\begin{array}{l}\text { 骑行 } \\
\text { Bicycle }\end{array}$ & $1,654(536)$ & & & & & & \\
\hline $\begin{array}{l}\text { 私家车 } \\
\text { Private car }\end{array}$ & $\mathrm{N} / \mathrm{A}$ & & & & & & \\
\hline $\begin{array}{l}\text { 公共交通 } \\
\text { Public transport }\end{array}$ & $1,720(675)$ & & & & & & \\
\hline
\end{tabular}

督；第三作者利用地理信息系统进行了初始数据分析；第一作者进行 了数据统计分析并撰写了本篇论文。

\section{3 研究结果}

在本次问卷调查中，描述性数据有助于研究者获取学生们在 5 个工 作日内的日常行为、出行目的地, 以及出行方式的详细信息 (表1)。 与儿童出行轨迹相关的具体活动位置均被一一标出。此外，通过图 1 可 以看到, 学生的离校后活动频率存在很大差异: 大约四分之三的学生 在5日内每天至少进行一次MVPA，而约13\%的学生则不进行MVPA。 of the surveys. The third author conducted the initial data analysis in a geographical information system. The first author conducted the statistical analysis and wrote this paper.

\section{Results}

Descriptive data is useful in this case because researchers obtained highly detailed information about what the children had done over a 5 -weekday period, as well as where and how they have traveled (Table 1). The specific locations of activities in relation to their travel trajectories were reported separately. There would also be enormous variation in the afterschool activities among the children (Fig. 1). About three quarters of the students report at least one MVPA per day, but about 13\% report no such MVPA outside commuting over the 5 weekdays. 

surveyed students
表 1 体现出了同一城市区域内的城中村儿童与正规居住区儿童在出 行活动方面存在的巨大差异。尽管城中村儿童的住所离学校更远, 但 他们更多地通过步行和骑行上学, 而非公交和地铁。这两种不同类型 社区之间的积极出行距离也存在显著差异一一城中村儿童每天的步行 和骑行距离比正规居住区儿童多出 $305 \mathrm{~m}$ 。此外, 城中村儿童放学回家 路线的变化程度更高，他们的MVPA程度也比正规居住区儿童更高。 尽管正规居住区儿童的课外班时间约为城中村儿童的三倍, 但整体来 看, 儿童在课外班花费的时间与其MVPA程度没有显著关联。需要指出 的是, 正规居住区儿童进行的MVPA多来自有组织的运动 (如在课外班 中进行的舞蹈训练等)。

影响出行模式选择的原因包括住所与学校之间的距离等因素。深 圳市的学区规划旨在最大程度地缩短住所一学校距离, 这一政策也适 用于包括城中村在内的紧凑型社区, 尽管住在这些社区内的儿童上学 途中可能仍需步行较长的距离。在本研究中, 城中村比正规居住区距 离学区内的学校更远。

在对多种出行方式进行多项回归分析之前, 首先应验证自变量是 否存在共线性。研究结果显示, 自变量之间的相关性为 $-0.089 \sim 0.091$, 因此变量之间不存在共线性。由于每份问卷均由学生独自完成, 从而 确保了问卷答案的独立性。如上所述, 出行模式的选择与提出的解释 变量之间存在明显的线性关系。研究对学生在 5 日内的平均出行距离进 行了多项回归分析, 以分析这一因素对出行方式选择的影响关系。

模型拟合表明, 解释变量显著增加了模型的精度 (卡方 $=239.4$, 自 由度 $=24, p=0.000)$ 。表 2 的伪决定系数 $\mathrm{R}^{2}$ 估值表明, 出行模式差异在 很大程度上可通过独立变量进行解释。似然比检验揭示了多项回归模 型中变量对于出行模式选择的影响。该模型显示, 出行距离以及是否 居住在城中村是显著影响出行模式的两个因素。此外, 男孩比女孩更

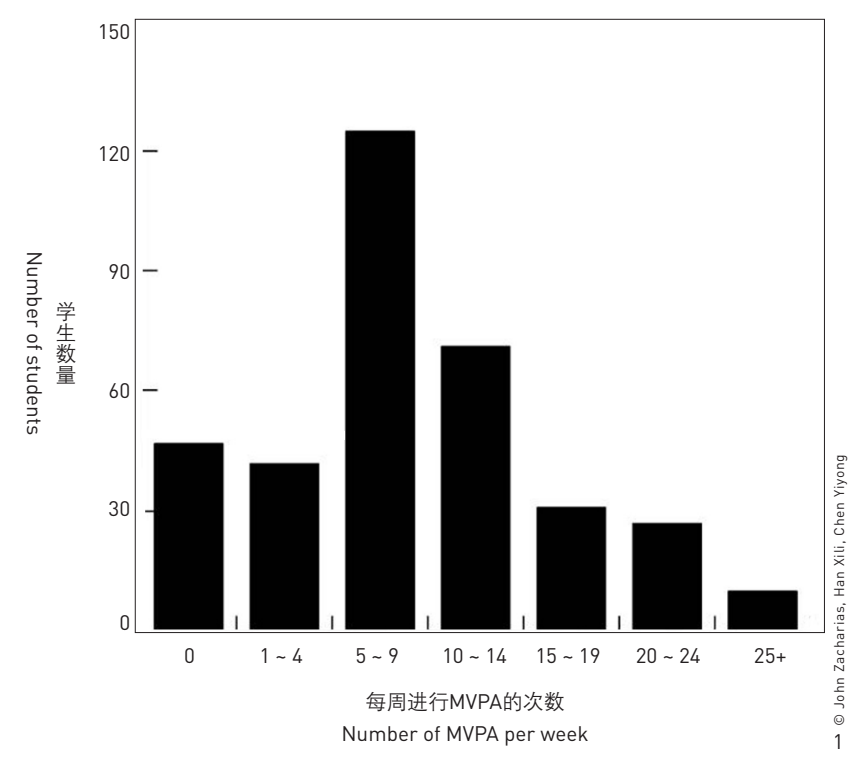

Table 1 reveals the significant differences between the activities of children living in urban villages and those in the planned residential areas within the same urban area. Urban village children travelled significantly farther to school. The greater distance that urban village children travelled to school has not caused greater reliance on bus and metro modes but more walking and bicycling from school and home. Active commuting distance between the two types of community was also significantly different, such that those children in the urban village were walking and bicycling $305 \mathrm{~m}$ more daily than the children in the planned residential communities. Also, urban village children extend their trip home to a greater extent. The number of MVPA among village children was greater than that of gated community children. There was no significant relation between the amount of time spent in cram schools and MVPA across the whole population, although children in planned residential areas had nearly three times the amount of cram school activity as did their village counterparts. It should be noted, however, that many MVPA of the planned residential area children were organized exercise (such as dance training in cram schools).

The choice of commuting mode could be highly sensitive to several issues, including the distance to school. The planning of school districts in Shenzhen makes distance minimization between home and school a very high priority. This practice makes for compact districts such as urban villages where some students may still travel considerable distances on foot. In this case, urban villages were located farther from the local school than planned residential areas.

Multiple options for travel suggest a multinomial regression analysis, but the rules for application of this model need to be considered first. Correlations between independent variables varied between -0.089 and 0.091 , eliminating the possibility of collinearity among variables. The survey was conducted individually and without consultation among students such that response independence was assured. As discussed above, there is an apparent linear relationship between mode choice and the proposed explanatory variables. The mean commuting distance of 5 weekdays in one week was used in the multinomial logistic model for travel mode choice.

Model fitting indicated that the explanatory variables add significantly to the model (chi-square $=239.4 ; \mathrm{df}=24$; $p=0.000$ ). The pseudo $\mathrm{R}^{2}$ estimates (Table 2 ) suggested a substantial proportion of variance in travel mode explained by the independent variables. The Likelihood Ratio Tests revealed the roles of the variables in the multinomial regression model for mode choice. Commuting distance and residence in an urban 
表2：离校交通方式选择的多项回归分析

Table 2: Multinomial regression for travel mode choice from school to home

\begin{tabular}{|c|c|c|c|c|}
\hline \multirow[b]{2}{*}{$\begin{array}{l}\text { 效应 } \\
\text { Effect }\end{array}$} & \multirow{2}{*}{$\begin{array}{c}\begin{array}{c}-2 \text { 倍对数似然值 } \\
-2 \text { Log likelihood of }\end{array} \\
\begin{array}{c}\text { 简化模型 } \\
\text { Reduced model }\end{array}\end{array}$} & \multicolumn{3}{|c|}{$\begin{array}{c}\text { 似然比检验 } \\
\text { Likelihood ratio tests }\end{array}$} \\
\hline & & $\begin{array}{c}\text { 卡方 } \\
\text { Chi-square }\end{array}$ & $\underset{d f}{\text { 自由度 }}$ & $\begin{array}{c}\text { 显著水平 } \\
\text { Sig. }\end{array}$ \\
\hline $\begin{array}{l}\text { 截距 } \\
\text { Intercept }\end{array}$ & 604.1 & 0.000 & 0 & - \\
\hline $\begin{array}{l}\text { 年齢 } \\
\text { Age }\end{array}$ & 610.9 & 6.802 & 3 & 0.078 \\
\hline $\begin{array}{l}\text { 出行距离 } \\
\text { Commuting distance }\end{array}$ & 736.6 & 132.553 & 3 & 0.000 \\
\hline $\begin{array}{l}\text { 课外班数量 } \\
\text { Number of cram schools }\end{array}$ & 608.4 & 4.330 & 3 & 0.228 \\
\hline $\begin{array}{l}\text { 中高强度体力活动 } \\
\text { MVPA }\end{array}$ & 609.5 & 5.434 & 3 & 0.143 \\
\hline $\begin{array}{l}\text { 性别 } \\
\text { Sex }\end{array}$ & 613.7 & 9.614 & 3 & 0.022 \\
\hline $\begin{array}{l}\text { 是否居住在城中村 } \\
\text { Living in an urban } \\
\text { village or not }\end{array}$ & 617.3 & 13.199 & 3 & 0.004 \\
\hline $\begin{array}{l}\text { 学校本身的因素 } \\
\text { Factor of school itself }\end{array}$ & 610.624 & 6.541 & 6 & 0.365 \\
\hline \multirow{2}{*}{$\begin{array}{l}\text { 伪 } R^{2} \\
\text { Pseudo } R^{2}\end{array}$} & Cox and Snell & \multicolumn{2}{|c|}{ Nagelkerke } & McFadden \\
\hline & 0.487 & \multicolumn{2}{|c|}{0.538} & 0.284 \\
\hline
\end{tabular}

有可能通过步行或骑行独自出行。尽管年龄的信度水平接近 $95 \%$ ，但 需要注意的是, 接受本次问卷调查的学生年龄跨度只有 3 岁, 且不包括 初三年级学生。

有趣的是, 与研究最初的假设相反, 儿童参加课外班的频次与出 行方式无关。研究人员原以为, 课外班造成的时间压力以及放学后为 了尽快将孩子从学校送到课外班会导致机动车出行的增加; 但收集到 的数据表明, 这些学生多通过步行方式前往课外班。毫无疑问, 这是 因为课外班多开设在居住区附近, 以便学生与家长就近上课。另一个 研究假设反差是, 研究人员曾认为, 私家车或公交出行会极大地限制 学生离校后活动的进行; 但结果显示MVPA的数量与出行方式的选择无 关, 这可能是由于学区内的住所一学校距离相对较短, 故而机动车对 MVPA的影响较小。最后, 学校本身 (例如是否倡导学生选择某种出行 方式）对于学生出行方式的影响并不显著。

本次调研仅针对三所中学; 随着样本量的扩大, 能够采集到的 学区内的学生地理位置数据也将更加多样, 可能会导致不同的调研结 果。本研究发现地理位置因素显著影响出行方式的选择, 如能采集到 深圳市内更多中学的学生样本, 将有望进一步探明地理位置因素对出 行方式的影响。 village were highly significant in the model. Boys were more likely to travel independently on foot or by bicycle. Age was nearly significant at the $95 \%$ confidence level, but it should be remembered that there was a span of only three years of age among the surveyed students, with the final year students excluded.

Interestingly, and in contrast with initial hypothesis, the number of cram schools attended was unrelated to travel mode. Researchers had thought that time pressures and the need to move children from school to another location after school would lead to the use of motorized travel options. However, it was apparent when inspecting the original data that a substantial proportion of those children going to cram schools after school did so on foot. Undoubtedly, such supplementary private education is often provided nearby for the convenience of the children and the families. Also contrary to the expectations, the amount of MVPA was also unrelated to travel mode choice. It had been thought that the use of a private car or public transport would greatly limit the possibilities of afterschool play. This may be due to the distance between 
本次研究针对MVPA进行了线性回归分析, 对诸如足球、篮球、羽 毛球、网球、乒乓球、游泳、滑冰、骑自行车、踢键子、跳舞、器械 锻炼等体力活动进行统计; 研究不计入每项运动的持续时间（表3)。 本次分析的解释变量包括性别、年龄、课外班数量、上下学的出行方 式、是否居住在城中村, 以及平均出行距离。各种通勤方式的参数估 计显示出相似的特性。

如上所述, 课外班的频次和出行方式的选择对MVPA的数量没有显 著影响。城中村儿童的MVPA数量多于正规居住区儿童。本次针对初中 生的调查显示, 年龄的增长与MVPA数量在一定程度上呈现负相关, 即 年龄越大, 进行MVPA的频次越低。最后, 性别是造成MVPA水平差异 的主要因素, 即男孩进行的MVPA更多。

\section{4 讨论}

显然, 大多数儿童在放学途中都会涉及积极出行, 而城中村儿童 的平均积极出行距离比正规居住区儿童多出 $305 \mathrm{~m}$ 。出行方式与距离高 度相关: 在一定阈值内, 出行距离越长, 步行或骑行距离越大; 当距离 达到某一特定阈值时, 出行方式即会从步行和骑行转变为机动车出行。

正规居住区儿童参加课外班的数量是城中村儿童的三倍, 但如此 高强度的课后学习并未对MVPA的数量及出行方式的选择产生影响。

表3: MVPA线性回归分析 Table 3: Linear regression for MVPA

\begin{tabular}{|c|c|c|c|c|c|}
\hline \multirow{2}{*}{\multicolumn{4}{|c|}{$\begin{array}{l}\text { MVPA模型 } \\
\text { MVPA model }\end{array}$}} & \multicolumn{2}{|c|}{$\begin{array}{l}\text { 方差分析 } \\
\text { ANOVA }\end{array}$} \\
\hline & & & & $D^{2}$ & F值 \\
\hline $\begin{array}{c}\text { 解释变量 } \\
\text { Explanatory variable }\end{array}$ & $\begin{array}{c}\text { 系数 } \\
\text { Coefficient }\end{array}$ & $\begin{array}{l}\text { 标准误差 } \\
\text { Std. Error }\end{array}$ & $\begin{array}{c}\text { 标准化的 } \beta \text { 值 } \\
\text { Std. } \beta\end{array}$ & \multirow{7}{*}{0.066} & \multirow{7}{*}{$4.147^{* * *}$} \\
\hline $\begin{array}{l}\text { 性别 } \\
\text { Sex }\end{array}$ & $-2.910^{* * *}$ & 0.760 & -0.200 & & \\
\hline $\begin{array}{l}\text { 年齢 } \\
\text { Age }\end{array}$ & $-1.029 *$ & 0.533 & -0.101 & & \\
\hline $\begin{array}{l}\text { 课外班数量 } \\
\text { Nummer of cram schools }\end{array}$ & 0.162 & 0.232 & 0.037 & & \\
\hline $\begin{array}{l}\text { 放学后的出行方式 } \\
\text { Commute mode afterschool }\end{array}$ & -0.081 & 0.239 & -0.021 & & \\
\hline $\begin{array}{l}\text { 是否居住在城中村 } \\
\text { Living in un urban village or not }\end{array}$ & $1.450 *$ & 0.847 & 0.097 & & \\
\hline $\begin{array}{l}\text { 放学后的平均出行距离 } \\
\text { Average commuting distance } \\
\text { afterschool }\end{array}$ & 0.001 & 0.001 & 0.098 & & \\
\hline
\end{tabular}

注

*代表 $p<0.10 ; * \star *$ 代表 $p<0.05 ; * * \star$ 代表 $p<0.01$ 。

NOTE

* means $p<0.10$; ** means $p<0.05$; *** means $p<0.01$ residence and school in the school district was relatively close, so the impact of motor vehicles on MVPA was relatively limited. Finally, the schools themselves (such as whether advocating one kind of transport mode or not) were not significant in the result.

However, the sampling of just three schools suggests a larger sample might reveal somewhat different results because of some geographical variation across the entire sample of such schools. In particular, the impact of geography on travel mode choice was clearly important in this sample, such that the effect of geography could be expected to be amplified in a larger sample of middle schools in Shenzhen.

A linear regression was proposed concerning MVPA, where all the individual activities were counted, though duration was not taken into account (Table 3). Examples of such activities included: football, basketball, badminton, tennis, table tennis, swimming, skating, bicycle riding, shuttlecock, dancing, and fitness equipment training, among others. The explanatory variables were the following: sex, age, the number of cram schools, mode of transport to school, living in an urban village, and average commuting distance to school. The parameter estimated for modes showed similar characteristics across the modes.

As suggested earlier, the intensity of afterschool cram education and travel mode choice had no significant impact on the amount of MVPA. Village children had more MVPA than did children living in planned communities. Increase in age from 12 to 15 had a modestly negative impact on MVPA, children had declining rates of MVPA as they mature. Finally, most of the variance in the model was explained by the sex of the child, with boys engaging in much more MVPA.

\section{Discussion}

It was evident that the school commute for the majority of students involves active transport. Urban village children travelled $305 \mathrm{~m}$ actively farther than did children in planned residential communities. Travel mode was sensitive to distance: within a certain threshold, the longer the commute, the greater the distance travelled on foot or by bicycle. However, there was a shift occurring from walking and bicycling to motorized modes at specific thresholds across all schools.

Students living in planned residential communities had three times as many cram school sessions as children living in urban villages. Such an intense schedule of afterschool academic training had no relation with the number of MVPA or the transport mode chosen for the commute. The number of sedentary activities reported by students is correlated with the 
调查结果显示, 久坐活动的数量与 MVPA的数量显著相关 $(r=0.504$, $p=0.000)$ 。此外, 调查问卷考察的多为有组织活动, 学生在自然状态 下的某些非常活跃的自由活动可能由于无法与问卷中的活动类别相匹 配而未被统计; 问卷涵盖了诸如做作业这样的久坐活动, 因为这些活 动较易列举、匹配。

研究发现正规居住区儿童与城中村儿童之间存在很大差异。一 般而言, 城中村儿童在放学路上花费的时间更长, 且积极出行程度更 高。研究同时发现, 学生的积极出行距离越长, 活动范围就越广, 活 动的程度也越高。在一项针对深圳市小学生积极出行的基于更大样本 数量的调查中, 也发现了类似的研究结果 ${ }^{[21]}$ 。

此外, 有待进一步探究的问题是: 引发出行模式转变的距离阈值 为多少? 尽管学生在放学后有积极出行和进行MVPA的意愿, 是什么阻 碍了多达 $58 \%$ 的城中村儿童的积极出行? 例如, 障碍物和安全隐患等 因素是否会对步行和骑行造成影响? 鉴于本次调查中学生的自行车使 用率相对较低 (12.8\%), 说明上述阻碍可能确实是导致出行方式转变 (由骑行转变为机动车出行) 的重要因素。

总体而言, 与澳大利亚、美国、加拿大、苏格兰、英格兰和新西 兰同类型研究中的儿童 ${ }^{[7]}$ 相比, 深圳12 15岁儿童在放学途中更为活 跃, 进行的MVPA也更多。显然, 中国华南地区的城市规划实践有效促 进了当地儿童的积极出行。尽管如此, 相关人员可以并应该开展更多 工作, 以培养儿童积极出行的良好习惯, 使其受益终身。本次调查未 对初三学生的活动方式进行评估, 这一欠缺应在未来的研究中予以弥 补。应学校的要求, 初三学生所有的课外活动时间都被家庭作业和补 习班所填满; 但也应当意识到, 这样一整年的高强度学习不仅会影响 学生的身体健康, 也会影响他们的心理和情绪状态。这种竞争性训练 的目的是为了在升学考试中获得足够高的分数以进入优质高中, 而这 些高中可能离家很远。而在高中最后一学年中, 学生将进行另一轮强 化学习以备战高考。这种恶性循环对青少年健康的影响有待进一步研 究。中国人 (包括儿童群体) 的肥胖率迅速攀升, 这些事实都在提醒 人们应当采取措施来扭转这一趋势。 number of MVPA ( $\mathrm{r}=0.504 ; p=0.000)$. It remained possible, however, that some free activities that were quite active in nature go unreported because it did not easily fit the organized sports activities in the questionnaire. Some uncoded sedentary activities were reported where they fit easily identified categories, such as homework.

There was a significant divide between the children living in planned residential communities and those living in urban villages. In general, the urban village children engage in longer commutes, and are more active. It is also found that the longer the active commute, the greater the territorial coverage, and number of activities. A similar result was seen in the active commutes of primary school children in Shenzhen on a much larger sample ${ }^{[21]}$.

How long is the distance threshold for triggering a change in travel mode? Given the willingness to extend the afterschool active commute and engage in MVPA, what is impeding the adoption of such active commutes by as many as $58 \%$ of the children, in the case of the urban villages? Answers require additional study. For example, barriers and security dangers may impede active commutes. The relatively low rate of bicycle $(12.8 \%)$ use among middle school children suggests such barriers might be important in promoting a shift to motorized travel.

Overall, children between 12 and 15 years of age in Shenzhen tend to be more active in their commutes and engage in more MVPA than do children studied in other contexts in Australia, the USA, Canada, Scotland, England, and New Zealand $^{[7]}$. Clearly, local urban planning plays a major role in promoting the active commute for young children in south China. Nevertheless, more could and should be done so that habits of active transport can be carried through adolescence and into adulthood. The inability to assess the activity regimes of grade 3 middle school students should be addressed in future study. The schools declared that all extra-curricular activities of grade 3 students were replaced with homework and additional cram schools for regular curriculum, which would impact not only the physical health of the children but also their mental and emotional state undergoing this intensive education year. The purpose of such competitive training is to obtain sufficiently high marks to enter reputable high schools, which may be located at some considerable distance from home. Another round of intensive training and the nationwide university entrance exams takes place in the final year of high school. The impact of such cycles on children's health deserves more study. The rapid rise in obesity rates in China, including among children, calls for measures to reverse the trend. 


\section{5 研究启示}

本次研究对于了解中国城市儿童的离校后活动状况具有重要意 义。尽管人们通常认为课外班会减少儿童的体力活动数量, 但本次研 究并未在针对初一、初二年级学生的调查中证实这一点。紧凑型学区 的规划实践有助于促进儿童的积极出行，这是城市规划的重大成功。 研究表明深圳市的儿童积极出行比率远高于国际案例; 与美国的研究结 果所不同的是, 居住在城市环境较差区域 (如深圳城中村) 中的儿童 比居住在正规居住区内的儿童更加活跃。当达到一定阈值时, 随着距 离的增加, 积极出行不断减少, 这表明虽然在学区规划实践下, 住所 一学校距离相对较近, 但机动车保有率的不断提升仍可能影响积极出 行。这一问题有待于基于当前研究的初步结论进行进一步调研。目前 的城市规划有助于促进儿童的积极出行, 但仍需进一步削减日益增加 的机动车辆、宽马路、障碍物等因素对儿童出行造成的不利影响。LAF

\section{Implications}

This study is a rare contribution to knowledge about children's afterschool activity in Chinese cities. Although it is often suggested that cram schools diminish the amount of physical activity among children, researchers did not find this in study results on children in the lower middle school grades. The planning of compact school districts to enable active commutes by the children can be seen as a major urban planning success. The children's active commute rate in Shenzhen is much higher than that reported in international cases. In contrast with results from the USA, children from the more disadvantaged urban environments, urban villages in the case of Shenzhen, are more active than children from privileged residential communities. The decline in active commutes as distance increases (when a distance threshold occurs) may be the consequence of increasing motorization, although the school district policy has effectively shortened the distance between home and school. Further examination of this point is warranted, based on these preliminary results. Current urban planning contributes to active travel of children and needs further adjustment to mitigate the effects of increasing motorization, bigger roads, and physical barriers to movement. LAF

\section{REFERENCES}

[1] Piontak, J. R., \& Schulman, M. D. (2016). School contex matters: The impacts of concentrated poverty and racial segregation on childhood obesity. Journal of School Health, 86(12), 864-872. doi:10.1111/josh. 12458

[2] Miao, J., \& Wu, X. (2016). Urbanization, socioeconomic status and health disparity in China. Health and Place, (42), 87-95. doi:10.1016/j.healthplace.2016.09.008

[3] NCD Risk Factor Collaboration. (2016). Trends in adult bodymass index in 200 countries from 1975 to 2014: A pooled analysis of 1698 population-based measurement studies with 19.2 million participants. Lancet, 387(10026), 1377-1396. doi:10.1016/S0140-6736(16)30054-X

[4] Wang, Y., Mi, J., Shan, X., Wang, Q., \& Ge, K. (2007). Is China facing an obesity epidemic and the consequences? The trends in obesity and chronic disease in China. International Journal in obesity and chronic disease in China. International

[5] Ng, S. W., Norton, E. C., \& Popkin, B. M. (2009). Why have physical activity levels declined among Chinese adults? Findings from the 1991-2006 China health and nutrition surveys. Social Science and Medicine, 68(7), 1305-1314. doi:10.1016/j.socscimed.2009.01.035

[6] Ng, S. W., Howard, A. G., Wang, H. J., Su, C., \& Zhang, B. (2014]. The physical activity transition among adults in China: $1991-$ 2011. Obesity Reviews, 15(S1), 27-36. doi:10.1111/obr.12127

[7] BJTRC (Beijing Transport Research Center). (2015). Beijing Transport Annual Report 2015. Retrieved from http://www. bjtrc.org.cn/List/index/cid/7.html

[8] Lee, M. C., Orenstein, M. R., \& Richardson, M. J. (2008). Systematic review of active commuting to school and children's physical activity and weight. Journal of Physical
Activity and Health, 5(6), 930-949. doi:10.1123/jpah.5.6.930

[9] Wickel, E. E., \& Belton, S. (2016). School's out ... now what? objective estimates of afterschool sedentary time and physical activity from childhood to adolescence. Journal of Science and Medicine in Sport, 19(8), 654-658. doi:10.1016 j.jsams.2015.09.001

[10] Yang, X, Telama, R., Hirvensalo, M.,. Tammelin, T., Viikari, J., \& Raitakari, O. T. (2014). Active commuting from youth ., \& Raitakari, O. T. (2014). Active commuting from youth
to adulthood and as a predictor of physical activity in early midlife: the Young Finns Study. Preventive Medicine, (59), 5-11. doi:10.1016/j.ypmed.2013.10.019

[11] Health Promotion Board (HPB). (2018). What is MVPA? Retrieved from http://www.nus.edu.sg/uhc/docs/defaultsource/default-document-library/what-is-mvpa.pdf?

[12] McDonald, N. C., Deakin, E., \& Aalborg, A. E. (2010). Influence of the social environment on children's school travel. Preventive Medicine, (50), 565-568. doi:10.1016) j.ypmed.2009.08.016

[13] Steinbach, R., Green, J., Edwards, P. (2012). Look who's walking: social and environmental correlates of children's walking in London. Health and Place , 18(4), 917-927. doi: 10.1016/j.healthplace.2012.02.005

[14] The Central Committee of the Communist Party of China \& The State Council. (1980, December 3). Decision of the Central Committee of the Communist Party of China and the State Council on Several Issues of Universal Primary Education. Retrieved from http://www.chinalawedu.com/falvfagui/ fg22598/368.shtml

[15] Panter, J., Jones, A., Van Sluijs, E., \& Griffin, S. J. (2011). The influence of distance to school on the association between active commuting and physical activity. Pediatric exercise science, 23(1), 72-86. https://doi.org/10.1123/pes.23.1.72

[16] Arundell, L., Hinkley, T., Veitch, J., \& Salmon, J. (2015). Contribution of the after-school period to children's daily participation in physical activity and sedentary behaviours. Plos One, 10(10), 1-11. doi:10.1371/journal.pone.0140132

[17] Southward, E. F., Page, A. S., Wheeler, B. W, \& Cooper A. R. (2012). Contribution of the school journey to daily physical activity in children aged 11-12 years. American Journal of Preventive Medicine, 43(2), 201-204. doi:10.1016/ j.amepre.2012.04.015

[18] Lee, J. E., Stodden, D. F., \& Gao, Z. (2016). Young children's energy expenditure and moderate-to-vigorous physical activity on weekdays and weekends. Journal of Physical Activity and Health, 13(9), 1013-1016. doi:10.1123/jpah.2015-0725

[19] Sirard, J. R., Riner, W. F., Mclver, K. L., \& Pate, R. R. (2005). Physical activity and active commuting to elementary school. Medicine and Science in Sports and Exercise, 37(12), 20622069. doi:10.1249/01.mss.0000179102.17183.6b

[20] Gao, Y., Wang, J., Lau, P. W. C., \& Ransdell, L. (2015). Pedometer-determined physical activity patterns in a segmented school day among Hong Kong primary school children. Journal of Exercise Science \& Fitness, 13(1), 42-48. doi:10.1016/j.jesf.2015.03.002

[21] Zacharias, J., Zhen, B., Han, X., \& Huang, Y. (2017). Local environment and social factors in primary school children's afterschool commute in China. Preventive medicine reports, (7), 206-210. doi:10.1016/j.pmedr.2017.06.012 